\title{
Accurate Determination of Boron Content in Halite by ICP-OES and ICP-MS
}

\author{
Zhang-kuang Peng $\mathbb{C}^{1}$ and Zhi-na Liu $\mathbb{B}^{1,2}$ \\ ${ }^{1}$ School of Earth Sciences and Resources, China University of Geosciences, 100083 Beijing, China \\ ${ }^{2}$ No. 208 Geologic Party, CNNC, Baotou 014010, Inner Mongolia, China \\ Correspondence should be addressed to Zhi-na Liu; zhinaliu88@163.com
}

Received 22 October 2018; Revised 9 April 2019; Accepted 10 April 2019; Published 29 May 2019

Academic Editor: Monica Gulmini

Copyright ( 2019 Zhang-kuang Peng and Zhi-na Liu. This is an open access article distributed under the Creative Commons Attribution License, which permits unrestricted use, distribution, and reproduction in any medium, provided the original work is properly cited.

\begin{abstract}
Boron element is widely distributed in different geologic bodies, and there are important geo-chemical applications in earth science. Halite is a common mineral found in sediment basin. However there is no good method to accurately measure the boron content in halite, which is mainly because Inductively Coupled Plasma Optical Emission Spectrometer (ICP-OES) and Inductively Coupled Plasma Mass Spectrometer (ICP-MS) are limited by the high salt matrix interference and the instrument detection limit. Thus enriching the boron element and removing the matrix interference are necessary before the measuring. In this paper, Amberlite IRA 743 boron-specific resin was applied to enrich the boron element and remove most of the high-salt matrix. The strong acid cation resin (Dowex $50 \mathrm{~W} \times 8,200-400$ mesh, USA) and weak-base anion resin (Ion Exchanger II, Germany) were mixed with equal volume, which could remove the foreign ions completely: meanwhile, the relative content of boron in the solution reached above $98 \%$, and the recoveries ranged from $97.8 \%$ to $104 \% .208 .900 \mathrm{~nm}$ was chosen as the detection wavelength for ICP-OES, and the detection identification and quantification limits were $0.006 \mathrm{mg} \cdot \mathrm{L}^{-1}$ and $0.02 \mathrm{mg} \cdot \mathrm{L}^{-1}$, respectively. ${ }^{11} \mathrm{~B}$ was chosen as the measuring element for ICP-MS, and the detection identification and quantification limits were severally $0.036 \mathrm{mg} \cdot \mathrm{L}^{-1}$ and $0.12 \mathrm{mg} \cdot \mathrm{L}^{-1}$. The relative standard deviations ranged from $1.4 \%$ to $3.4 \%$ through six replicates under different salinities. Therefore, the process could be regarded as a feasible method to measure boron content in halite by ICP-OES and ICP-MS.
\end{abstract}

\section{Introduction}

The boron is a strongly incompatible element in the earth [1], which makes the boron remain in the solution during the evaporation, and, with the development of evaporation, the boron content in the halite increases [2,3]. As the boron gets into the halite in the form of inclusion, it could reflect the salinity of the paleo-lake water as well as drier paleoclimatic conditions. The geo-chemical behavior of boron in halite is a useful tool to study the evolution and chemical composition of salt lake [2-5]. However, there were few reports about measuring the boron content in halite. Spectrophotometry is a common method for the determination of boron content in many minerals, such as biological sample, soil, plants, and food [6-11]; meanwhile it was the only method to measure the boron content in boron-rich halite formed in laboratory [4]. Due to the low sensitivity and serious matrix interference, it is not good for measuring the boron content in natural halite.
Because of the high sensitivity and rapid analysis, the ICPMS and ICP-OES are good methods for measuring the boron content in different minerals, such as coal, quartz, and other geochemical samples [12-15]. However, there was no report about using ICP-MS and ICP-OES to measure the boron content in halite. Though dilution is the commonest method to overcome the high-salt matrix interference, it is not for measuring the boron content in halite because it will cause the boron content in the solution to fall below the detection limit of the instrument. So preenrichment of boron element and reducing the salinity from solution are the keys to successfully measure the boron content in halite by ICP-OES or ICP-MS. In this paper, Amberlite IRA 743 boron-specific resin was used to enrich boron and remove most of the $\mathrm{NaCl}$. Then elute the adsorbed boron from the resin with hydrochloric acid, whose volume, content, and temperature were $10 \mathrm{~mL}$, $0.1 \mathrm{~mol} \cdot \mathrm{L}^{-1}$, and $75^{\circ} \mathrm{C}$, respectively. The conditions of eluent were reported by Xiao et al., who found that the boron was 
TABLE 1: The recoveries of boron in pure solutions.

\begin{tabular}{lcc}
\hline Total amount of boron $/ \mu \mathrm{g}$ & Total recovery amount of boron $/ \mu \mathrm{g}$ & Recovery $/ \%$ \\
\hline 10 & 9.76 & 97.6 \\
30 & 30.27 & 100.9 \\
50 & 49.60 & 99.20 \\
70 & 71.64 & 102.34 \\
\hline 10 & 10.2 & 102 \\
30 & 30.0 & 100 \\
50 & 49.4 & 98.8 \\
70 & 70.3 & 100.4 \\
\hline
\end{tabular}

hard to be eluted from the boron-special resin even if the concentration of $\mathrm{HCl}$ reached $2 \mathrm{~mol} \cdot \mathrm{L}^{-1}$, while it can be easily eluted by $\mathrm{HCl}$ in high temperature [16]. The strong acid cation resin (Dowex $50 \mathrm{~W} \times 8,200-400$ mesh, USA) and weak-base anion resin (Ion Exchanger II, Germany) were mixed with equal volume to remove $\mathrm{NaCl}$ and $\mathrm{HCl}$. Finally send the solution to measure boron content by ICP-OES and ICP-MS.

\section{Material and Methods}

2.1. Apparatus. Inductively Coupled Plasma Optical Emission Spectrometry (ICP-OES, ICAP 6500 DUO, Thermo Electron): RF power was $1150 \mathrm{~W}$; flux of cooling air was 15 $\mathrm{L} \cdot \mathrm{min}^{-1}$; flux of auxiliary air was $0.5 \mathrm{~L} \cdot \mathrm{min}^{-1}$; flux of carryingair was $0.55 \mathrm{~L} \cdot \mathrm{min}^{-1}$; pump speed was $60 \mathrm{r} \cdot \mathrm{min}^{-1}$; observation way of plasma was automatic.

Inductively Coupled Plasma Mass Spectrum (ICP-MS, X series 2 type, Thermo Electron): RF power was $1250 \mathrm{~W}$; flux of cooling air (Ar) was $12.0 \mathrm{~L} \cdot \mathrm{min}^{-1}$; flux of auxiliary was $0.75 \mathrm{~L} \cdot \mathrm{min}^{-1}$; atomizer flow $(\mathrm{Ar})$ was $0.85 \mathrm{~L} \cdot \mathrm{min}^{-1}$; measuring method was peak jumping with ${ }^{11} \mathrm{~B}$.

2.2. Reagents. Boric acid solid $\left(\mathrm{H}_{3} \mathrm{BO}_{3}, \mathrm{GR}\right)$ and sodium chloride solid ( $\mathrm{NaCl}, \mathrm{GR})$ were made in Beijing Reagent Factory. Balanced hydrochloric acid was made from concentrated hydrochloric acid (GR): sub-boiling ammonia. Deionized water was made through multiple distillation and then the boron was removed by Amberlite IRA 743 type boronspecific resin made in American Rohm \& Hass Company. It contains hydrophobic styrene skeleton and tertiary amine group and can strongly adsorb borate anion from alkaline

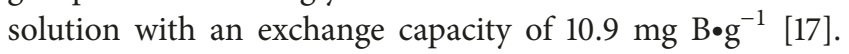
Mixed resin was made of an equal volume of strong acid cation resin (Dowex $50 \mathrm{~W} \times 8,200-400$ mesh, USA) and weakbase anion resin (Ion Exchanger II, Germany).

Natural Samples: natural salt samples came from ZK309 Drill Hole, Long-hu Diggings, Laos (ZK-03, ZK-04, ZK-10), and salt lake in Pakistan (KR03-2, BS01-2, KS05).

2.3. Certified Reference Materials, Samples, and Sample Preparation. Prepare a standard solution of $10 \mathrm{mg} \cdot \mathrm{L}^{-1}$ boron, and then use it and $\mathrm{NaCl}$ to make a series of mixtures with boron content from $10 \mu \mathrm{g}$ to $70 \mu \mathrm{g}$ and $\mathrm{NaCl}$ from $500 \mathrm{mg} \cdot \mathrm{L}^{-1}$ to $50000 \mathrm{mg} \cdot \mathrm{L}^{-1}$. Because the boron was only adsorbed by boron-special resin in the form of $\mathrm{B}(\mathrm{OH})_{4}{ }^{-}$in the alkaline solution, the sub-boiling ammonia is used to adjust the $\mathrm{pH}$ of the solution to 7 8 [18], and then the purification process of boron-specific resin is carried out by previous studies [7]. Boron is eluted from the resin with $10 \mathrm{~mL} 0.1 \mathrm{~mol} \cdot \mathrm{L}^{-1} \mathrm{HCl}$ at $75^{\circ} \mathrm{C}$, and then mix the strong acid cation resin (Dowex $50 \mathrm{~W} \times 8,200-400$ mesh, USA) and weak-base anion resin (Ion Exchanger II, Germany) with equal volume to remove the foreign ions from the eluent. Finally determine boron content by ICP-OES and ICP-MS. During step one, the boron is adsorbed by boron-special resin in the form of $\mathrm{B}(\mathrm{OH})_{4}{ }^{-}$. Next the foreign ions are adsorbed by the mixed resins in which the boron exists in the form of $\mathrm{H}_{3} \mathrm{BO}_{3}$ in solution, and it is separated from foreign ions.

For numbers ZK-03, ZK-04, ZK-10, KR03-2, BS01-2, and KS05, weight $5.0 \mathrm{~g}$ halite and dissolve them into $50 \mathrm{~mL}$ deionized water. Remove the high-salt matrix and enrich the boron element using the above method.

\section{Result and Discussion}

3.1. The Result of Boron Recovery. The recovery of boron in the pure solutions ranged from $97.6 \%$ to $102.34 \%$ (Table 1), which indicated that the boron is not lost during the adsorption and eluting, and all the boron could be recovered completely by the resins. Comparing the values measured by ICP-OES with those by ICP-MS, they were found to be consistent (Figure 1) and the same as the contents of boron in original solutions.

The recoveries of boron in solutions under different salinities ranged from $99.95 \%$ to $103.3 \%$ (Table 2), which were consistent with the results of pure solution and showed that the salinity had no effect on the adsorption of boron-specific resin and mixed resins. The results demonstrated that the high salt matrix interference of the solution could be excluded effectively, which is suitable for the detection of the boron content by ICP-OES and ICP-MS after removing the high-salt matrix and enriching the boron element. And this method provided a good way to measure the boron content in halite.

The recovery of additional standard of the natural halite (ZK-04, ZK-10) ranged from $98.8 \%$ to $106.00 \%$ (Table 3 ), which showed that all the boron of the natural halite was recovered completely by resins. The dissolution of the halite in water, as well as the enrichment and removal of the matrix in the resins, did not result in the loss of boron. There was no 
TABLE 2: The recovery results of boron in different salinities.

\begin{tabular}{lccccc}
\hline $\begin{array}{l}\text { The content of } \\
\mathrm{Na}^{+} \mathrm{mg} \cdot \mathrm{L}^{-1}\end{array}$ & $\begin{array}{c}\text { amount of } \\
\text { boron } / \mu \mathrm{g}\end{array}$ & $\begin{array}{c}\text { Measuring by } \\
\text { ICP-OES } \\
\mathrm{mg} \cdot \mathrm{L}^{-1}\end{array}$ & $\begin{array}{c}\text { Measuring by } \\
\text { ICP-MS } \\
\mathrm{mg} \cdot \mathrm{L}^{-1}\end{array}$ & $\begin{array}{c}\text { Recovery } \\
\text { for ICP-OES \% }\end{array}$ & $\begin{array}{c}\text { Recovery for } \\
\text { ICP-MS } \%\end{array}$ \\
\hline 500 & 40 & 4.053 & 4.132 & 101.33 & 103.3 \\
5000 & 40 & 4.112 & 4.023 & 102.8 & 100.57 \\
50000 & 40 & 4.181 & 3.998 & 104.5 & 99.95 \\
\hline
\end{tabular}

TABLE 3: The recovery additional standard for natural sample.

\begin{tabular}{|c|c|c|c|c|c|}
\hline Sample number & $\begin{array}{l}\text { Measuring } \\
\text { method }\end{array}$ & $\begin{array}{l}\text { Boron content } \\
\text { of original } \\
\text { solution } \\
\mathrm{mg} \cdot \mathrm{L}^{-1}\end{array}$ & $\begin{array}{l}\text { The amount of } \\
\text { addition } \\
\text { standard / } \mu \mathrm{g}\end{array}$ & $\begin{array}{l}\text { Boron content of } \\
\text { additional standard } \\
\text { solution } \mathrm{mg} \cdot \mathrm{L}^{-1}\end{array}$ & $\begin{array}{c}\text { Recovery } \\
\text { additional } \\
\text { standard \% }\end{array}$ \\
\hline \multirow{2}{*}{ ZK-04 } & ICP-OES & 1.029 & 10 & 2.089 & 106.00 \\
\hline & ICP-MS & 1.075 & 10 & 2.129 & 105.40 \\
\hline \multirow{2}{*}{ ZK-10 } & ICP-OES & 0.832 & 10 & 1.82 & 98.8 \\
\hline & ICP-MS & 0.803 & 10 & 1.842 & 104.2 \\
\hline
\end{tabular}

TABLE 4: The separation effect by boron-special resin and mixed resins.

\begin{tabular}{|c|c|c|c|c|c|c|c|}
\hline \multirow{2}{*}{ Sample } & \multicolumn{4}{|c|}{ The amount of ions / $\mu \mathrm{g}$} & \multirow{2}{*}{ Total amount of foreign ions / $\mu \mathrm{g}$} & \multirow{2}{*}{ The amount of boron $/ \mu \mathrm{g}$} & \multirow{2}{*}{ The relative content / $\%$} \\
\hline & $\mathrm{Na}^{+}$ & $\mathrm{Li}^{+}$ & $\mathrm{Mg}^{2+}$ & $\mathrm{Cl}^{-}$ & & & \\
\hline Big Qaidam & 0.2 & 0 & 0.08 & 0.13 & 0.41 & $24.3(24.1)$ & 98.3(98.3) \\
\hline Inter-crystalline Brine & 0.26 & 0.45 & 0.04 & 0.32 & 1.07 & $48.6(48.3)$ & $97.9(97.8)$ \\
\hline Lake water & 0.17 & 0 & 0.05 & 0.25 & 0.47 & $14.9(15.1)$ & $97.0(96.98)$ \\
\hline Synthetic brine & 0.08 & 0 & 0.02 & 0.1 & 0.2 & $17.6(17.5)$ & $98.9(98.87)$ \\
\hline Brine- 500 & 0.1 & 0 & 0 & 0.3 & 0.4 & $40.85(40.3)$ & $99.0(99.02)$ \\
\hline Brine- 5000 & 0.2 & 0 & 0 & 0.4 & 0.6 & $41.25(40.9)$ & $98.57(98.55)$ \\
\hline Brine- 50000 & 0.3 & 0 & 0 & 0.7 & 1.0 & $41.58(40.7)$ & $97.65(97.6)$ \\
\hline
\end{tabular}

* The data in the parentheses represented the results of measuring by ICP-MS, and the other data represented the results of measuring by ICP-OES.

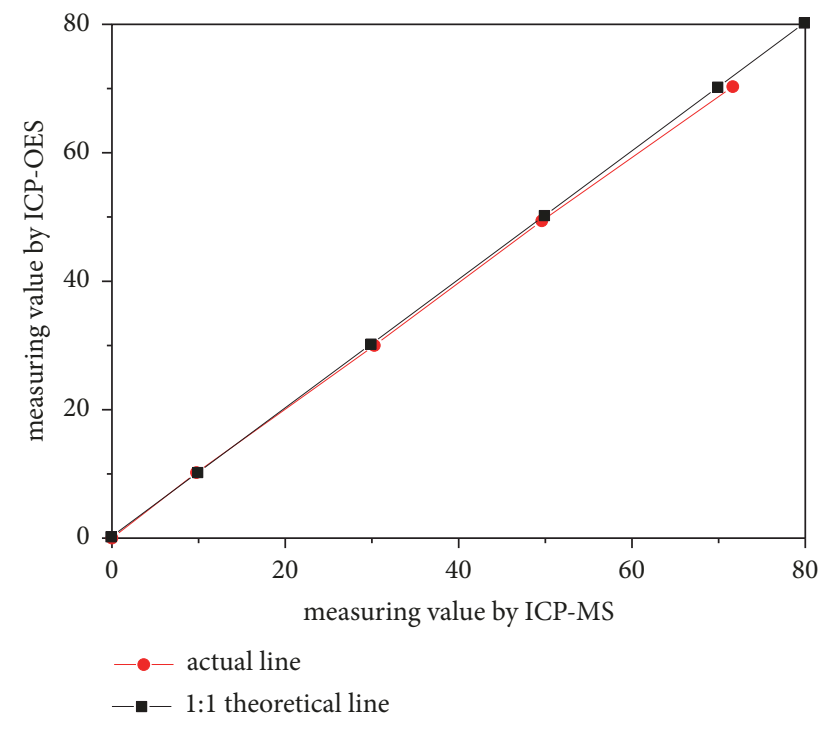

FIGURE 1: The relationship of measuring value by ICP-OES and ICPMS. The lines of actual values were consistent with the theoretical line of 1:1 which showed that the values measured by ICP-OES were the same as those by ICP-MS. difference between the boron contents of the halite measured by ICP-OES and ICP-MS.

3.2. Separating Effect by Resins. In order to discuss the separating effect between boron element and foreign ions, three natural samples and four synthetic brines were processed based on the above method. The amounts of foreign ions were measured, whose results (Table 4) showed that the foreign ions in the original solution were removed completely and the relative content of boron reached above $97 \%$. Thus this method was great for the detection of boron content by ICPOES and ICP-MS.

3.3. The Detection Identifications of Boron Content by ICPOES and ICP-MS. Take the deionized water through the entire process as a blank solution. Perform 11 consecutive measurements, and define 3 times standard deviation of the measurement results as the detection identification, 2 times the detection identification as the identification limit, and 10 times the standard deviation as the quantification limit for boron element [19]. All the parameters were showed in Table 5. If the salinity of the solution was reduced just by 
TABLE 5: The detection identification and quantification limits.

\begin{tabular}{lccccccc}
\hline Method & $\begin{array}{c}\text { Wavelength } \\
\mathrm{nm}\end{array}$ & $\begin{array}{c}\text { Average } \\
\text { content } \\
\mathrm{mg} \cdot \mathrm{L}^{-1}\end{array}$ & $\begin{array}{c}\mathrm{SD} \\
\mathrm{mg} \cdot \mathrm{L}^{-1}\end{array}$ & $\begin{array}{c}\text { RSD } \\
\%\end{array}$ & $\begin{array}{c}\text { detection } \\
\text { identification } \\
\mathrm{mg} \cdot \mathrm{L}^{-1}\end{array}$ & $\begin{array}{c}\text { identification } \\
\text { limit } \\
\mathrm{mg} \cdot \mathrm{L}^{-1}\end{array}$ & $\begin{array}{c}\text { quantification } \\
\text { limit } \\
\mathrm{mg} \cdot \mathrm{L}^{-1}\end{array}$ \\
\hline ICP-OES & 208.900 & -0.002 & 0.002 & 3.6 & 0.006 & 0.012 & 0.02 \\
\hline $\begin{array}{c}\text { analytical } \\
\text { isotope }\end{array}$ & $\begin{array}{c}\text { Average } \\
\text { content } \\
\mathrm{mg} \cdot \mathrm{L}^{-1}\end{array}$ & $\begin{array}{c}\mathrm{SD} \\
\mathrm{mg} \cdot \mathrm{L}^{-1}\end{array}$ & $\begin{array}{c}\mathrm{RSD} \\
\%\end{array}$ & $\begin{array}{c}\text { detection } \\
\text { identification } \\
\mathrm{mg} \cdot \mathrm{L}^{-1}\end{array}$ & $\begin{array}{c}\text { identification } \\
\text { limit } \mathrm{mg} \cdot \mathrm{L}^{-1}\end{array}$ & $\begin{array}{c}\text { quantification } \\
\text { limit } \\
\mathrm{mg} \cdot \mathrm{L}^{-1}\end{array}$ \\
\hline ICP-MS & ${ }^{11} \mathrm{~B}$ & 0.003 & 0.012 & 2.8 & 0.036 & 0.072 & 0.12 \\
\hline
\end{tabular}

TABLE 6: Repeated results under different salinities.

\begin{tabular}{|c|c|c|c|c|c|c|}
\hline \multirow{2}{*}{ number } & \multicolumn{2}{|c|}{$\mathrm{Na}^{+} 500 \mathrm{mg} \cdot \mathrm{L}^{-1}$} & \multicolumn{2}{|c|}{$\mathrm{Na}^{+} 5000 \mathrm{mg} \cdot \mathrm{L}^{-1}$} & \multicolumn{2}{|c|}{$\mathrm{Na}^{+} 50000 \mathrm{mg} \cdot \mathrm{L}^{-1}$} \\
\hline & By ICP-OES & By ICP-MS & By ICP-OES & By ICP-MS & By ICP-OES & By ICP-MS \\
\hline 1 & 4.417 & 4.374 & 4.231 & 4.500 & 4.387 & 4.407 \\
\hline 2 & 4.165 & 4.357 & 4.408 & 4.396 & 4.208 & 4.385 \\
\hline 3 & 4.363 & 4.246 & 4.336 & 4.626 & 4.547 & 4.677 \\
\hline 4 & 4.255 & 4.334 & 4.249 & 4.413 & 4.227 & 4.743 \\
\hline 5 & 4.425 & 4.275 & 4.438 & 4.369 & 4.468 & 4.646 \\
\hline 6 & 4.437 & 4.385 & 4.365 & 4.325 & 4.556 & 4.458 \\
\hline $\begin{array}{l}\text { average value } \\
\left(\mathrm{mg} \cdot \mathrm{L}^{-1}\right)\end{array}$ & 4.344 & 4.329 & 4.338 & 4.438 & 4.440 & 4.553 \\
\hline SD & 0.11 & 0.06 & 0.08 & 0.11 & 0.15 & 0.15 \\
\hline RSD (\%) & 2.5 & 1.4 & 1.8 & 2.5 & 3.4 & 3.3 \\
\hline
\end{tabular}

dilution, it would cause the boron content of the solution to be lower than the detection limit and quantification limit of ICP-OES and ICP-MS.

3.4. The Method Repeatability Test. Repeatedly test solutions at different salinities 6 times, whose results which were showed in Table 6 indicated that the standard deviation ranged from $1.4 \%$ to $3.4 \%$, and all the values were less than $5 \%$. So we think that the method is feasible and there is no accidental error for the boron content determination of halite by ICP-OES and ICP-MS.

3.5. The Boron Contents of Natural Samples. The boron contents of natural samples which were showed in Figure 2 ranged from $0.3684 \mathrm{mg} \cdot \mathrm{L}^{-1}$ to $1.029 \mathrm{mg} \cdot \mathrm{L}^{-1}$, the measuring values of which were beyond the identification limits and the quantification limits of ICP-OES and ICP-MS. The values of natural halite measured by ICP-OES were consistent with those by ICP-MS. Conversely, if only dilution was performed, the boron content in the solution would be similar to the detection limit and the quantitation limit of the instrument; therefore the dilution method could not be applied for the detection of boron content of the halite by ICP-OES and ICPMS. Comparing the boron content of the halite of Longhu Diggings, Laos (ZK-03, ZK-04, ZK-10), with that of the salt lake in Pakistan (KR03-2, BS01-2, KS05), we found that the boron contents in Laos halite were higher than those in Pakistan halite. This result was consistent with the geological

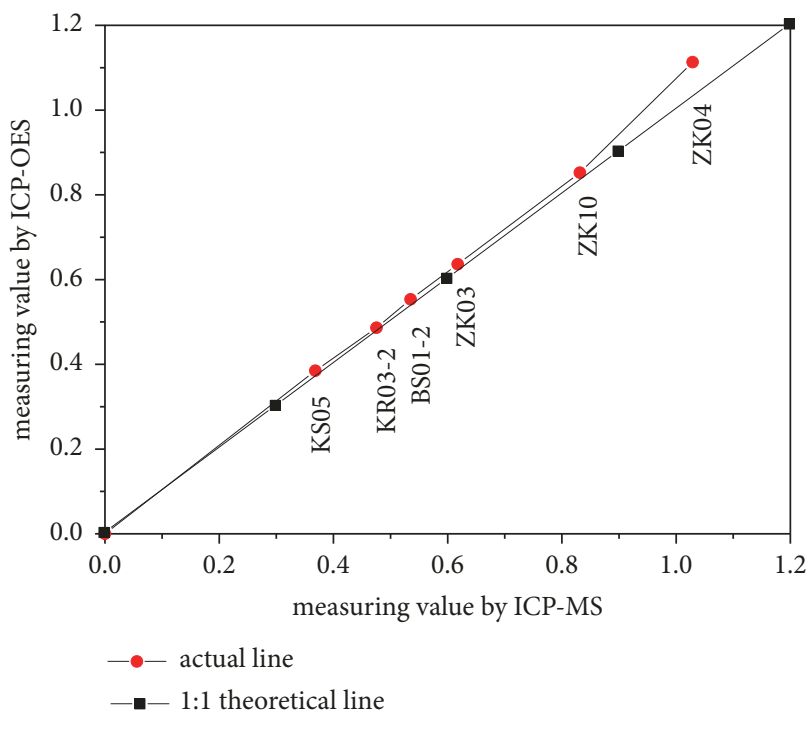

FIGURE 2: The boron content of natural halite.

phenomenon that there are borate mineral inclusions in Long-hu Diggings, Laos [20, 21].

\section{Conclusion}

The boron-specific resin could significantly enrich the boron in high-salt solution and remove the matrix, which is suitable 
for the detection of the boron content of halite by ICP-OES and ICP-MS, whose standard addition recovery ranged from $97.5 \%$ to 106.0 , and the relative standard deviations of the repeated experiments were less than $5 \%$.

\section{Data Availability}

The data used to support the findings of this study are included within the article.

\section{Conflicts of Interest}

The authors declare that they have no conflicts of interest.

\section{References}

[1] W. P. Leeman and V. B. Sisson, "Geochemistry of boron and its implications for crustal and mantle processes," in Boron: Mineralogy, Petrology and Geochemistry, Reviews in Mineralogy, E. S. Grew and L. M. Anovitz, Eds., vol. 33, pp. 645-695, Mineralogical Society of America, Washington, D.C., USA, 1996.

[2] Y. S. Du, Q. S. Fan, D. L. Gao et al., "Evalution of boron isotopes in halite as an indicator of the salinity of Qarhan paleolake water in the eastern Qaidam Basin, western China," Geoscience Frontiers, no. 1, pp. 1-10, 2019.

[3] Q. S. Fan, Y. Q. Ma, H. D. Chen et al., "Boron occurrence in halite and boron isotope geochemistry of halite in the Qarhan Salt Lake, western China," Sedimentary Geology, vol. 322, pp. 34-42, 2015.

[4] W. G. Liu, Y. K. Xiao, Z. C. Peng, Z. S. An, and X. X. He, "Boron concentration and isotopic composition of halite from experiments and salt lakes in the Qaidam Basin," Geochimica Et Cosmochimica Acta, vol. 64, no. 13, pp. 2177-2183, 2000.

[5] G. Paris, J. Gaillardet, and P. Louvat, "Geological evolution of seawater boron isotopic composition recorded in evaporites," Geology, vol. 38, no. 11, pp. 1035-1038, 2010.

[6] M. A. Wimmer and H. E. Goldbach, "A miniaturized curcumin method for the determination of boron insolutions and biological samples," Journal of Plant Nutrition and Soil Science, vol. 162, pp. 15-18, 1999.

[7] Y. K. Xiao, B. Y. Liao, W. G. Liu et al., "Ion exchange extraction of boron from aqueous fluids by Amberlite IRA 743 resin," Chinese Journal of Chemistry, vol. 21, no. 8, pp. 1073-1079, 2003.

[8] S. Thangavel, S. M. Dhavile, K. Dash, and S. C. Chaurasia, "Spectrophotometric determination of boron in complex matrices by isothermal distillation of borate ester into curcumin," Analytica Chimica Acta, vol. 502, no. 2, pp. 265-270, 2004.

[9] D. M. Gomes, M. A. Segundo, J. L. Lima, and A. O. Rangel, "Spectrophotometric determination of iron and boron in soil extracts using a multi-syringe flow injection system," Talanta, vol. 66, no. 3, pp. 703-711, 2005.

[10] R. Shekhar, J. Arunachalam, G. R. Krishna, H. R. Ravindra, and B. Gopalan, "Determination of boron in $\mathrm{Zr}-\mathrm{Nb}$ alloys by glow discharge quadrupole mass spectrometry," Journal of Nuclear Materials, vol. 340, no. 2-3, pp. 284-290, 2005.

[11] L. Zaijun, C. Zhengwei, and T. Jian, "The determination of boron in food and seed by spectrophotometry using a new reagent 3,4-dihydroxyazomethine-H," Food Chemistry, vol. 94, no. 2, pp. 310-314, 2006.
[12] F. G. Smith, D. R. Wiederin, R. S. Houk, C. B. Egan, and R. E. Serfass, "Measurement of boron concentration and isotope ratios in biological samples by inductivey coupled plasma mass spectrometry with direct injection nebulization," Analytica Chimica Acta, vol. 248, no. 1, pp. 229-234, 1991.

[13] A. M. S. Nyomora, R. N. Sah, P. H. Brown, and R. O. Miller, "Boron determination in biological materials by inductively coupled plasma atomic emission and mass spectrometry: effects of sample dissolution methods," Fresenius' Journal of Analytical Chemistry, vol. 357, no. 8, pp. 1185-1191, 1997.

[14] C. H. Yang and S. J. Jiang, "Determination of B, Si, P and $\mathrm{S}$ in steels by inductively coupled plasma quadrupole mass spectrometry with dynamic reaction cell," Spectrochimica Acta Part B: Atomic Spectroscopy, vol. 59, no. 9, pp. 1389-1394, 2004.

[15] A. G. Coedo, M. T. Dorado, and I. Padilla, "Evaluation of different sample introduction approaches for the determination of boron in unalloyed steels by inductively coupled plasma mass spectrometry," Spectrochimica Acta Part B: Atomic Spectroscopy, vol. 60, no. 1, pp. 73-79, 2005.

[16] Y. K. Xiao, Y. Xiao, G. H. Swihart, and W. G. Liu, “The investigation of ion exchange technique for extracting boron from aqueous fluids by boron specific ion exchange resin," Acta Geoscientia Sinica, vol. 18, pp. 286-289, 1997.

[17] J. K. Aggarwal, M. B. Shabani, M. R. Palmer, and K. V. Ragnarsdottir, "Determination of the rare earth elements in aqueous samples at sub-ppt levels by inductively coupled plasma mass spectrometry and flow injection ICPMS," Analytical Chemistry, vol. 68, pp. 4418-4423, 1996.

[18] W. P. Leeman, R. D. Vocke Jr., E. S. Beary, and P. J. Paulsen, "Precise boron isotopic analysis of aqueous samples: Ion exchange extraction and mass spectrometry," Geochimica et Cosmochimica Acta, vol. 55, no. 12, pp. 3901-3907, 1991.

[19] V. Sandroni, C. M. M. Smith, and A. Donovan, "Microwave digestion of sediment, soils and urban particulate matter for trace metal analysis," Talanta, vol. 60, no. 4, pp. 715-723, 2003.

[20] H. B. Tan, H. Z. Ma, B. K. Li, X. Y. Zhang, and Y. K. Xiao, "Strontium and boron isotopic constraint on the marine origin of the khammuane potash deposits in southeastern laos," Chinese Science Bulletin, vol. 55, pp. 3181-3188, 2010.

[21] X. Y. Zhang, H. Z. Ma, Y. Q. Ma, Q. L. Tang, and X. L. Yuan, "Origin of the late Cretaceous potash-bearing evaporites in the Vientiane Basin of Laos: $\delta^{11}$ B evidence from borates," Journal of Asian Earth Sciences, vol. 62, pp. 812-818, 2013. 

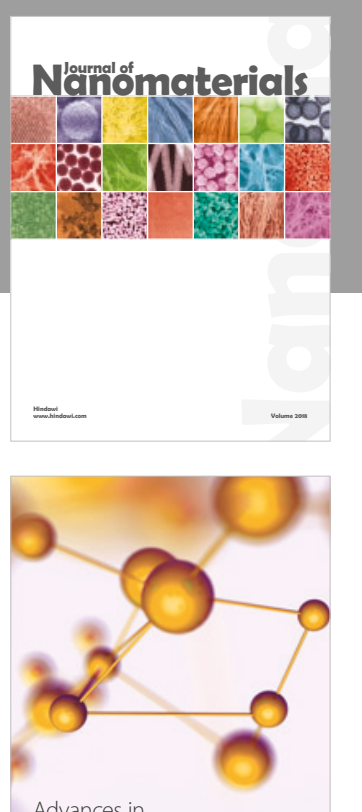

Physical Chemistry
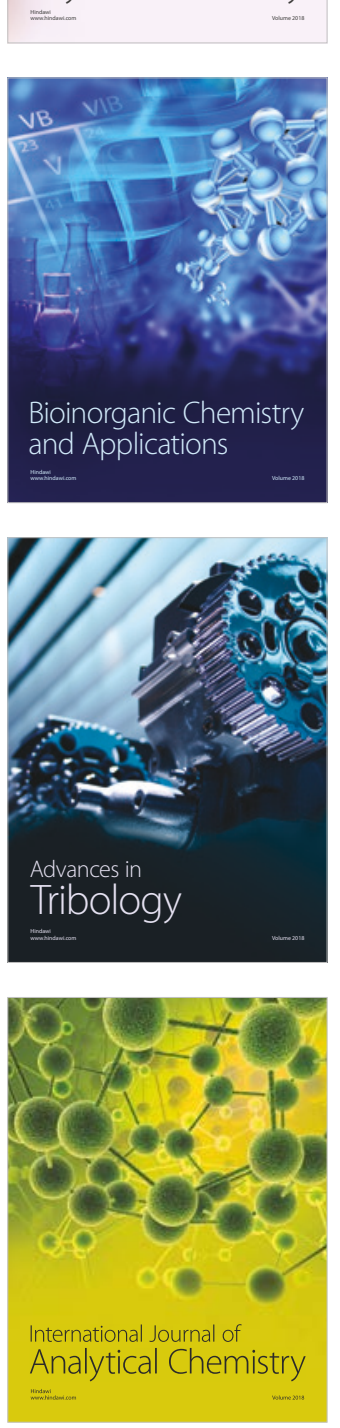

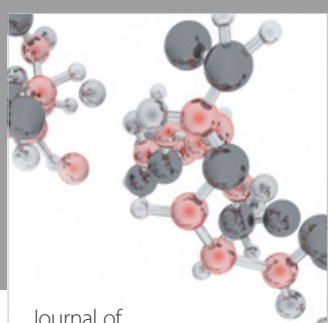

Analytical Methods

in Chemistry

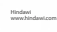

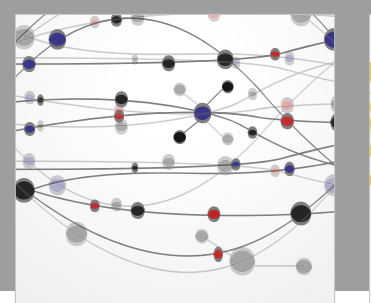

The Scientific World Journal

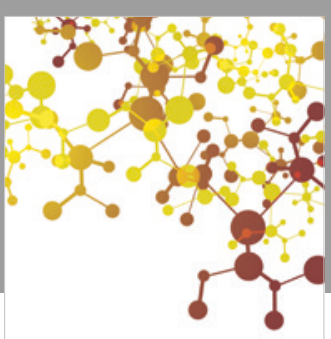

Journal of

Applied Chemistry
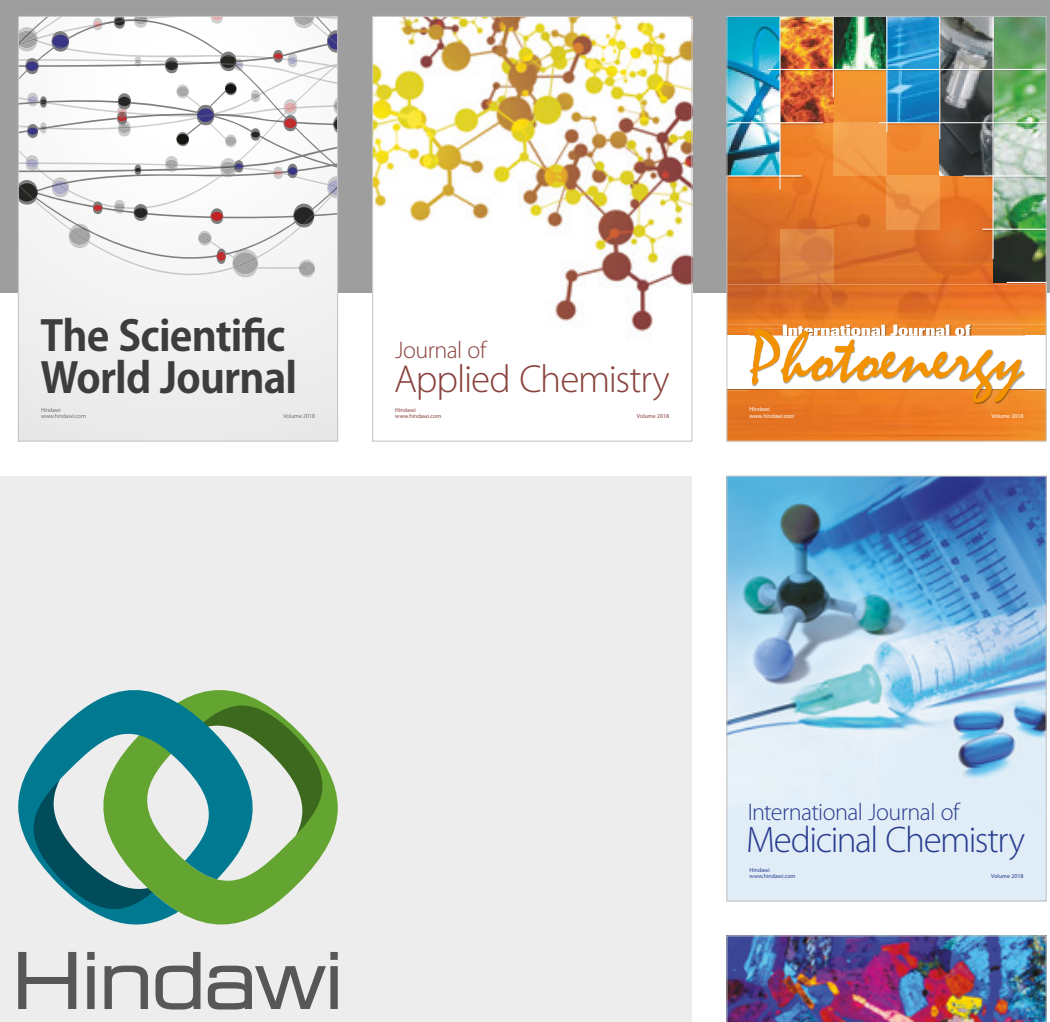

Submit your manuscripts at

www.hindawi.com
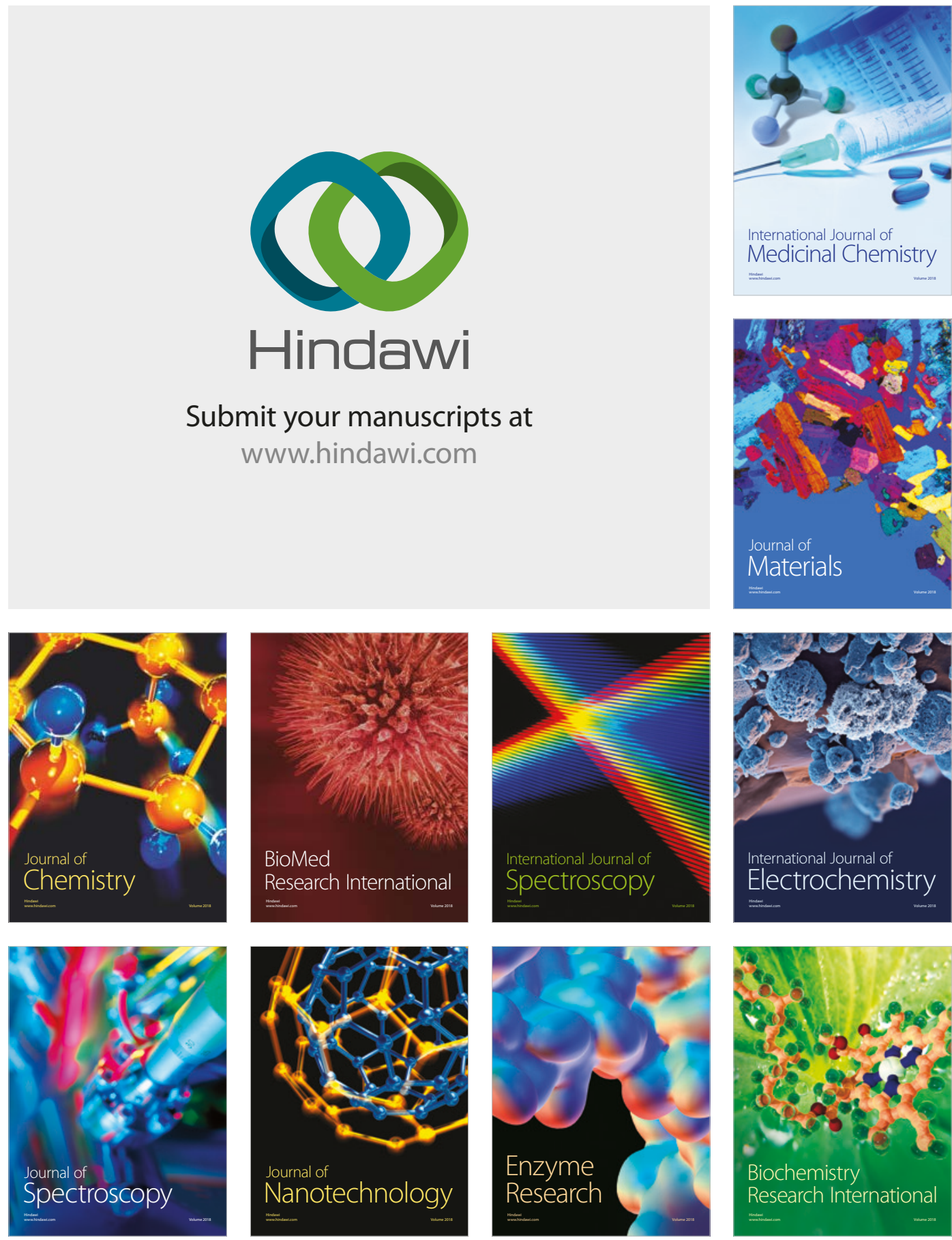
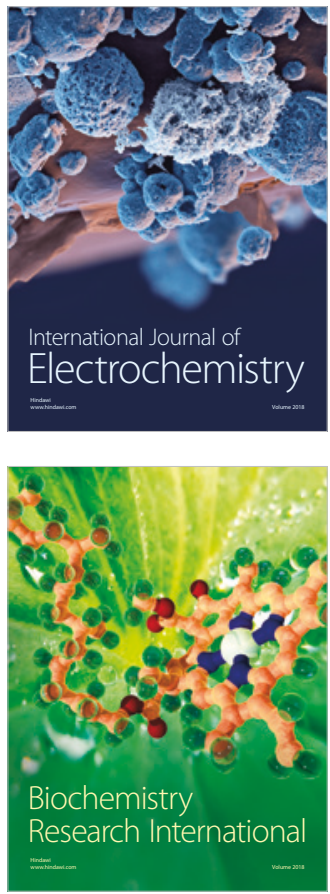